\title{
The First Amendment and Algorithms
}

\author{
Stuart Minor Benjamin
}

\section{INTRODUCTION}

If someone relies on algorithms ${ }^{1}$ to communicate to others, does that reliance change anything for First Amendment purposes? ${ }^{2}$ In this chapter I argue that, under the Supreme Court's prevailing jurisprudence, the answer is no. Any words or pictures that would be speech under the First Amendment if produced entirely by a human are equally speech if produced via human-created algorithm. So long as humans are making the decisions that underlie the outputs, a human is sending whatever message is sent. Treatment as speech requires substantive editing by a human being, whether the speech is produced via algorithm or not. If such substantive editing exists, the resulting communication is speech under the current jurisprudence. Simply stated, if we accept Supreme Court jurisprudence, the First Amendment encompasses a great swath of algorithm-based decisions - specifically, algorithm-based outputs that entail a substantive communication.

This has enormous significance. As the other chapters in this book - indeed, the existence of the book itself - highlight, algorithms are becoming increasingly important in our world. Part and parcel of the rise of transmission via bits has been transmission according to algorithms and protocols created by humans and implemented by machines. ${ }^{3}$ Messages travel over the Internet because of transmission protocols, coding decisions determine the look and feel of websites, and algorithms determine which links, messages, or stories rise to the top of search engine results and social media feeds. Every networked device depends on an electronic network built in part on algorithms. Indeed, with each passing day it becomes

1 There is no single accepted definition of “algorithm." See Algorithm Characterization, Wikipedia, http://en .wikipedia.org/wiki/Algorithm_characterizations (stating that an "[a]lgorithm does not have a generally accepted formal definition” and discussing more than twenty different prominent characterizations). Broadly speaking, an algorithm is a set of instructions designed to produce an output. My use of the term in this chapter focuses on its most common usage - as instructions or rules implemented by a computer. That is, I want to focus on non-human processes, and I use the term "algorithm" to refer to them. For ease, I will refer to decisions made by protocols, algorithms, and other computations as algorithm-based decisions. I could call them "code-based processes" or some other less familiar and more ungainly term, but I choose "algorithm" simply because it has become more familiar shorthand.

2 By "someone" I mean a speaker for First Amendment purposes, which the Supreme Court has long held includes individuals and associations, including corporations. And when I refer to the First Amendment I am referring to its Free Speech Clause component, even though the Amendment also contains other clauses.

3 I am using "bit" as a convenient shorthand for information transmitted via electronic signals. In computing and telecommunications, data is encoded in binary digits (also known as bits), but nothing in this chapter turns on the binary nature of bits per se. The point is simply to emphasize the nature of the communication as electronic, as opposed to old-fashioned pen or printing press on paper. 
a greater challenge to identify forms of electronic communication that do not rely on algorithms.

Around the turn of this century, there was considerable focus on whether computer code was speech for First Amendment purposes, such that regulations on the distribution of code implicated the First Amendment. ${ }^{4}$ The government had concerns about the proliferation of some computer programs (notably, those perceived as jeopardizing security), and it sought to regulate the circulation of the code itself - the instructions to a computer that would enable the feared activity. ${ }^{5}$ For what it is worth, the few courts that considered the issue found by and large that regulations of computer code were regulations of speech. ${ }^{6}$

My focus is not on the distribution of code, and thus not on whether code itself is speech. Rather, I consider whether the outputs of that code - the results produced by algorithms - are speech for First Amendment purposes. The question whether the First Amendment applies to regulation of algorithms' outputs is different from the question whether the algorithms themselves are speech. Even if the algorithms are not speech, their products may be.

What sorts of regulations of algorithm-based decisions might be at issue? The possibility that has inspired the most commentary is the regulation of search engine results, and in particular (given its large market share) Google. A company frustrated by its low PageRank (which hurt its ability to find clients) brought an action against Google for tortious interference with contractual relations, and Google successfully argued that the First Amendment applied to its search results. ${ }^{7}$ Another company frustrated by its rankings on Google unsuccessfully argued that Google's search engine is an "essential facility" that must be opened to access, ${ }^{8}$ and Frank Pasquale argued that Google should be understood as a new kind of bottleneck deserving of regulatory attention - an "essential cultural and political

4 See, e.g., S. E. Halpern, Harmonizing the Convergence of Medium, Expression, and Functionality: A Study of the Speech Interest in Computer Software (2000) 14 Harv. J. Law Technol. 139, 181 (discussing the application of the First Amendment to computer software); R. Post, Encryption Source Code and the First Amendment (2000) 15 Berkeley Technol. Law J. 713, 716 (discussing whether encryption source code is covered by the First Amendment); F. Schauer, The Boundaries of the First Amendment: A Preliminary Exploration of Constitutional Salience (2004) 117 Harv. Law Rev. 1765, 1794 ("The anti-Microsoft and anti-Hollywood claims of the open-source movement focus on the way in which computer source codes can be conceived of as a language and therefore as speech ...”); K. A. Moerke, Note, Free Speech to a Machine? Encryption Software Source Code Is Not Constitutionally Protected "Speech" under the First Amendment (2000) 84 Minn. Law Rev. 1007, 1027 ("[B] ecause source code is the implementation of an idea, not the expression of it, it is not entitled to First Amendment protection as a type of speech").

5 The government has acted on these concerns on a number of occasions by restricting the distribution or export of computer software that it viewed as dangerous on a number of occasions, producing several lawsuits. See, e.g., Jungerv. Daley, ${ }_{209}$ F.3d 481 (6th Cir. 2000) (export of encryption software programs); Bernstein v. Dep't of Justice, 176 F.3d 1132 (9th Cir. 1999) (distribution of encryption software pursuant to the International Traffic in Arms Regulations); Karn v. Dep't of State, 925 F. Supp. 1 (DDC 1996) (designation of a computer diskette as a “defense article" pursuant to the Arms Export Control Act and the International Traffic in Arms Regulations).

6 See Universal City Studios, Inc. v. Corley, 273 F.3d 429, 447 (2nd Cir. 2001) (holding that the First Amendment covers computer programs, and stating that “[a] recipe is no less 'speech' because it calls for the use of an oven, and a musical score is no less 'speech' because it specifies performance on an electric guitar”); Bernstein, 176 F.3 d at 1141 (concluding that "encryption software, in its source code form and as employed by those in the field of cryptography, must be viewed as expressive for First Amendment purposes"), reh'g en banc granted and opinion withdrawn, 192 F.3d 1308 (9th Cir. 1999).

7 Search King, Inc. v. Google Tech., Inc., No. 02-1457, 2003 WL 21464568, at *3-4 (WD Okla. May 27, 2003) (order granting Google's motion to dismiss). "PageRank" is an algorithm that "measure $[\mathrm{s}]$... the quantity and quality of links from one website to another." V. T. Nilsson, Note, You're Not from Around Here, Are You? Fighting Deceptive Marketing in the Twenty-First Century (2012) 54 Ariz. Law Rev. 801, 807; see also PageRank, Wikipedia, http://en.wikipedia.org/wiki/PageRank.

8 Kinderstart.com, LLC v. Google, Inc., No. o6-2057, 2007 WL 831806, at *4 (ND Cal. March 16, 2007) (granting motion to dismiss) ("KinderStart asserts that the Google search engine is 'an essential facility for the marketing and 
facility." Oren Bracha and Frank Pasquale have also argued that the government should be able to regulate search engines' ability to structure their results, and that the First Amendment does not encompass search engine results. ${ }^{10}$ Eugene Volokh and Donald Falk, by contrast, have contended that all aspects of search engines' results are fully protected by the First Amendment. ${ }^{11}$

Google has been the biggest flashpoint, but these issues are not limited to Google. ${ }^{12}$ Every major Internet platform relies on algorithms for searches and otherwise, and many of these companies have been criticized for using algorithms that have allowed coordinated misinformation or propaganda campaigns, most notoriously from Russian operations. ${ }^{13}$ These companies have often responded by changing their algorithms. For instance, YouTube modified its recommendation algorithms to produce substantively different results - notably, ones that are less likely to promote conspiracies or false information. ${ }^{14}$ Taking a somewhat different approach, Facebook changed its News Feed algorithms to display more content from users' friends and family and less from publishers. ${ }^{15}$

The stakes are high. More and more of our activity involves bits, and those bits are frequently guided and shaped by algorithms. The more fully algorithm-based decisions are treated as speech, the more broadly First Amendment jurisprudence will apply. And this has real consequences. Content-based government regulations of speech are subject to strict

financial viability of effective competition in creating, offering and delivering services for search over the Internet" (citation omitted)).

9 F. Pasquale, Dominant Search Engines: An Essential Cultural \& Political Facility, in B. Szoka and A. Marcus (eds.), The Next Digital Decade (TechFreedom, 2010), pp. 401, 402, http://nextdigitaldecade.com/ndd_book.pdf.

10 See O. Bracha and F. Pasquale, Federal Search Commission? Access, Fairness, and Accountability in the Law of Search (2008) 93 Cornell Law Rev. 1149, 1193-201 and n. 239 (contending that the First Amendment, properly understood, does not cover search engine rankings); see also J. A. Chandler, A Right to Reach an Audience: An Approach to Intermediary Bias on the Internet (2007) 35 Hofstra Law Rev. 1095, 1117 (stating that in light of websites' free speech "right to reach an audience, and the listener's right to choose among speakers according to the listener's own criteria, free of extraneous discriminatory influences[,] . . search engines should not manipulate individual search results except to address instances of suspected abuse of the system").

1 See E. Volokh and D. M. Falk, First Amendment Protection for Search Engine Search Results, White Paper (2012), p. 3, www.volokh.com/wp-content/uploads/2012/05/SearchEngineFirstAmendment.pdf. Volokh and Falk state that:

Google, Microsoft's Bing, Yahoo! Search, and other search engines are speakers. First, they sometimes convey information that the search engine company has itself prepared or compiled (such as information about places appearing in Google Places). Second, they direct users to material created by others, by referencing the titles of Web pages that the search engines judge to be most responsive to the query, coupled with short excerpts from each page ... Third, and most valuably, search engines select and sort the results in a way that is aimed at giving users what the search engine companies see as the most helpful and useful information.

James Grimmelmann has taken a more nuanced position, focusing on search engines as advisors to their users. See J. Grimmelmann, Speech Engines (2014) 98 Minn Law Rev. 868.

12 See T. M. Massaro, H. Norton, and M. E. Kaminski, Siri-Ously 2.o: What Artificial Intelligence Reveals about the First Amendment (2017) 101 Minn. Law Rev. 2481; R. K. L. Collins and D. M. Skover, Robotica: Speech Rights \& Artificial Intelligence (Cambridge University Press, 2018).

13 See M. Isaac and D. Wakabayashi, Russian Influence Reached 126 Million through Facebook Alone, New York Times (October 30, 2017) (stating that Facebook, Twitter, and YouTube acknowledged that "Russian agents intending to sow discord among American citizens disseminated inflammatory posts that reached 126 million users on Facebook, published more than 131,000 messages on Twitter and uploaded over 1,000 videos to Google's YouTube service").

14 See E. Dwoskin, YouTube Is Changing its Algorithms to Stop Recommending Conspiracies, Washington Post (January 25, 2019) (stating that YouTube "is retooling its recommendation algorithm that suggests new videos to users in order to prevent promoting conspiracies and false information”).

15 See K. Wagner, Facebook Is Making a Major Change to the News Feed that Will Show You More Content from Friends and Family and Less from Publishers, Recode (January 11, 2018). 
scrutiny, which is very difficult to satisfy. ${ }^{16}$ Content-neutral regulations are subject to intermediate scrutiny, which is an easier test to pass but still much more rigorous than the rational basis review applicable to ordinary regulation. ${ }^{17}$

Heightened scrutiny raises the costs of regulation, both in requiring more justification $e x$ ante and in increasing the likelihood that the regulation will be rejected on constitutional grounds (since the chances of rejection on constitutional grounds for ordinary legislation are near zero). It could be that we, as a society, like this outcome because we decide that we want less government regulation of algorithm-related industries, but my point here is simply that we disincentivize regulation when heightened scrutiny applies. Subjecting every regulation that affects algorithm-based transmissions to intermediate scrutiny would have dramatic consequences.

Consider the Court's 2011 opinion in Sorrell v. IMS Health Inc., ${ }^{18}$ which involved a Vermont law restricting the sale, disclosure, and use of pharmacy records that reveal the prescribing practices of individual doctors, as a way of thwarting data miners' perceived invasion of privacy. ${ }^{19}$ Such a law would be unproblematically constitutional absent First Amendment coverage. That is, if it were understood not to trigger First Amendment scrutiny, it would easily pass constitutional muster. But, the Supreme Court flatly stated in Sorrell that "[s]peech in aid of pharmaceutical marketing ... is a form of expression protected by the Free Speech Clause of the First Amendment. As a consequence, Vermont's statute must be subjected to heightened judicial scrutiny. The law cannot satisfy that standard."

Similarly, the Federal Communications Commission's (FCC) limits on the horizontal concentration and vertical integration of cable companies would be subject to fairly lenient review if applied to distributors of gas or electricity. But because the DC Circuit found that these regulations implicated the First Amendment and thus triggered intermediate scrutiny, the court invalidated the regulations and remanded them. ${ }^{21}$ Even after that remand, and a much more detailed analysis by the FCC, the DC Circuit found that the FCC had failed to justify the numbers it had chosen and thus rejected them again. ${ }^{22}$ Those limits - which are statutorily mandated - lie dormant. The FCC has not figured out how to write regulations that will survive heightened First Amendment scrutiny.

\section{SUPREME COURT JURISPRUDENCE AND ITS EXPANSION}

\section{Widely Accepted Sources and Forms of Reasoning}

In this chapter I want to apply widely accepted sources and forms of legal reasoning. In the First Amendment context, that means primarily Supreme Court jurisprudence. This is fairly

16 See, e.g., Sable Commc'ns of Cal., Inc. v. FCC, 492 US 115, 126 (1989) ("The Government may ... regulate the content of constitutionally protected speech in order to promote a compelling interest if it chooses the least restrictive means to further the articulated interest").

17 See, e.g., Turner Broad. Sys., Inc. v. FCC (Turner I), 512 US 622, 662 (1994) (“[A] content-neutral regulation will be sustained if 'it furthers an important or substantial governmental interest; if the governmental interest is unrelated to the suppression of free expression; and if the incidental restriction on alleged First Amendment freedoms is no greater than is essential to the furtherance of that interest"' (quoting United States v. O'Brien, 391 $\left.\left.\mathrm{US}_{3} 67,377(1968)\right)\right)$.

$18 \quad 564$ US $552(2011)$

19 Vt. Stat. Ann. tit. 18, $\$ 4631(d)(2010)$.

20 Sorrell, above note 18 , at 557 .

${ }^{21}$ Time Warner Entm't Co. v. FCC, 240 F.3d 1126, 1137, 1143-4 (DC Cir. 2001).

22 Comcast Corp. v. FCC, 579 F.3d 1, 10 (DC Cir. 2009). 
well-trodden ground, and my focus here is not to defend that proposition. I will simply note that, as a textual matter, "speech" and "the freedom of speech" could be interpreted in any number of ways. Everyone might agree on some core elements, but the textual boundaries of these terms are not apparent. And as Leonard Levy noted more than half a century ago, "[t]he meaning of no other clause of the Bill of Rights at the time of its framing and ratification has been [as] obscure to us" as that of the Free Speech Clause. ${ }^{23}$ Many commentators rely on underlying theories of the First Amendment - visions about what the freedom of speech really means, usually grounded in conceptions of the First Amendment's purpose. The main conceptions that have been offered over the years are the marketplace of ideas and the search for truth, self-government, democratic deliberation, personal autonomy, individual selfexpression, and the government-checking function. ${ }^{24}$ For better or worse, no underlying conception of the First Amendment has been widely accepted as explaining or driving First Amendment doctrine and thus none can fairly be described as a widely accepted source or form of reasoning. ${ }^{25}$

23 L. W. Levy, Freedom of Speech and Press in Early American History: Legacy of Suppression (Belknap Press, 1960), p. 4; see also S. C. Brubaker, Original Intent and Freedom of Speech and Press, in E. W. Hickok, Jr. (ed.), The Bill of Rights: Original Meaning and Current Understanding (1991), pp. 82, 85 ("The debates in Congress concerning the speech and press clauses shed scant light on the question of meaning... . Nor do we find enlightening comments in the state legislatures that considered the amendments or the local newspapers or pamphlets of the time”).

That said, Framing-era materials suggest that the Framing generation held a narrower conception of the freedom of speech than do modern courts, and many in the Framing generation adhered to Blackstone's position that the freedom of speech was best understood as a freedom from prior restraints. See, e.g., L. W. Levy, Jefferson and Civil Liberties: The Darker Side (Belknap Press, 1963), p. 46 ("Jefferson ... never protested against the substantive law of seditious libel ... He accepted without question the dominant view of his generation that government could be criminally assaulted merely by the expression of critical opinions that allegedly tended to subvert it by lowering it in the public's esteem”); Levy, Freedom of Speech and Press, p. xxi ("The evidence drawn particularly from the period 1776 to 1791 indicates that the generation that framed ... the First Amendment was hardly as libertarian as we have traditionally assumed"); R. H. Bork, Neutral Principles and Some First Amendment Problems (1971) 47 Ind. Law J. 1, 22 ("In colonial times and during and after the Revolution [early political leaders] displayed a determination to punish speech thought dangerous to government, much of it expression that we would think harmless and well within the bounds of legitimate discourse"); G. Edward White, Historicizing Judicial Scrutiny (2005) 57 SC Law Rev. 1, 60 ("Since the First Amendment only applied against Congress, this approach assumed that the federal government could punish seditious, libelous, blasphemous, obscene, or indecent speech with impunity so long as it did not censor the speech in advance"); see also W. Blackstone, Commentaries (Clarendon Press, 1769), Doc. 4, "151 ("The liberty of the press is indeed essential to the nature of a free state: but this consists in laying no previous restraints upon publications, and not in freedom from censure for criminal matter when published" (emphasis in the original)).

24 On the marketplace of ideas, see below notes 26-8 and accompanying text. On the search for truth, see generally W. P. Marshall, In Defense of the Search for Truth as a First Amendment Justification (1995) 30 Ga. Law Rev. 1. On self-government and democratic deliberation, see generally A. Meiklejohn, Free Speech and Its Relation to Self-Government (Harper Bros., 1948); R. C. Post, Constitutional Domains: Democracy, Community, Management (Harvard University Press, 1995), pp. 119-78; C. R. Sunstein, Democracy and the Problem of Free Speech (Simon \& Schuster, 1995); and H. Kalven, Jr., The New York Times Case: A Note on "The Central Meaning of the First Amendment” (1964) Sup. Ct. Rev. 191. On autonomy, see generally C. E. Baker, Human Liberty and Freedom of Speech (Oxford University Press, 1989), pp. 194-224; R. H. Fallon, Jr., Two Senses of Autonomy (1994) 46 Stan. Law Rev. 875; and H. H. Wellington, On Freedom of Expression (1979) 88 Yale Law J. 1105. On the checking function, see generally V. Blasi, The Checking Value in First Amendment Theory (1977) Am. B. Found. Res. J. 521. On self-expression, see generally M. H. Redish, Freedom of Expression: A Critical Analysis (Lexis, 1984); and D. A. J. Richards, Free Speech and Obscenity Law: Toward a Moral Theory of the First Amendment (1974) 123 U. Pa. Law Rev. 45.

25 See, e.g., T. I. Emerson, Toward a General Theory of the First Amendment (Random House, 1966), p. vii ("Despite the mounting number of decisions and an even greater volume of comment, no really adequate or comprehensive theory of the First Amendment has been enunciated, much less agreed upon"); D. A. Farber, The First Amendment, 2nd edn. (Foundation Press, 2003), p. 6 ("For a while there was a trend toward single-value theories 
The best-known conception, and that most commonly invoked by the Supreme Court, is the marketplace of ideas. ${ }^{26}$ For instance, the Supreme Court stated in Red Lion Broadcasting Co. v. FCC (in language quoted many times since) that "[i]t is the purpose of the First Amendment to preserve an uninhibited marketplace of ideas in which truth will ultimately prevail." 27 But the marketplace-of-ideas conception has many detractors, and the Supreme Court has emphasized different conceptions in some cases and in still other cases refrained from choosing any particular theory. ${ }^{28}$

Some theorists would argue (in mild rebuke to the Supreme Court) that one cannot usefully interpret the bare words of the Free Speech Clause without an underlying theory, and the Supreme Court (in mild rebuke to those theorists) interprets the Free Speech Clause without an agreed-upon theory. ${ }^{29}$ One way of understanding the first part of this chapter is

of First Amendment law, in which a scholar would posit a single underlying constitutional value and then attempt to deduce all First Amendment doctrine from that value. Such efforts, whatever their merits, never seemed to persuade many other scholars and were almost entirely ignored by the courts"); R. Post, Reconciling Theory and Doctrine in First Amendment Jurisprudence (2000) 88 Calif. Law Rev. 2353, 2372 (noting that the Supreme Court has not consistently followed any one theory of the First Amendment). The absence of a consensus in support of a particular theory of the First Amendment is not surprising: each possible conception of the First Amendment can be subjected to legitimate criticism, and reaching agreement at that level of specificity is difficult for any group, Justices or otherwise. The Supreme Court's First Amendment jurisprudence is thus one of the many areas characterized by incompletely theorized agreements. Cass Sunstein characterizes this phenomenon as follows:

Many judges are minimalists; they want to say and do no more than necessary to resolve cases ... [Minimalists] attempt to reach incompletely theorized agreements, in which the most fundamental questions are left undecided. They prefer outcomes and opinions that can attract support from people with a wide range of theoretical positions, or with uncertainty about which theoretical positions are best. In these ways, minimalist judges avoid the largest questions about the meaning of the free speech guarantee, or the extent of the Constitution's protection of “liberty," or the precise scope of the President's authority as Commander in Chief of the Armed Forces.

C. R. Sunstein, Minimalism at War (2004) Sup. Ct. Rev. 47, 48 (footnote omitted; emphasis in the original).

26 Justice Holmes's dissent in Abrams v. United States, 250 US 616 (1919), contains the first, and probably the most famous, articulation of the marketplace metaphor, one that "revolutionized not just First Amendment doctrine, but popular and academic understandings of free speech." J. Blocher, Institutions in the Marketplace of Ideas (2008) 57 Duke Law J. 821, 823-4. Holmes wrote:

$[\mathrm{W}]$ hen men have realized that time has upset many fighting faiths, they may come to believe even more than they believe the very foundations of their own conduct that the ultimate good desired is better reached by free trade in ideas - that the best test of truth is the power of the thought to get itself accepted in the competition of the market, and that truth is the only ground upon which their wishes safely can be carried out. That at any rate is the theory of our Constitution.

Abrams, 250 U.S. at 630 (Holmes, J., dissenting). See also Blocher, ibid., pp. 824-5 ("Never before or since has a Justice conceived a metaphor that has done so much to change the way that courts, lawyers, and the public understand an entire area of constitutional law. Its influence has been both descriptive and normative, dominating the explanation of and the justification for free speech in the United States").

27 Red Lion Broad. Co. v. FCC, 395 US 367,390 (1969).

28 See above note 25 and accompanying text; see also Hurley v. Irish-Am. Gay, Lesbian \& Bisexual Grp., 515 US 557 , 573-5 (1995) (emphasizing the centrality of autonomy to the First Amendment); Turner I, above note 17, at 641 ("At the heart of the First Amendment lies the principle that each person should decide for himself or herself the ideas and beliefs deserving of expression, consideration, and adherence"); First Nat'l Bank of Bos. v. Bellotti, 435 US 765,777 n. 11 (1978) ("Freedom of expression has particular significance with respect to government because " $\mathrm{i}] \mathrm{t}$ is here that the state has a special incentive to repress opposition and often wields a more effective power of suppression”" (quoting Emerson, above note 25, p. 9)); Mills v. Alabama, 384 US 214, 218 (1966) (“[A] major purpose of [the First] Amendment was to protect the free discussion of governmental affairs").

29 See, e.g., Post, above note 4, p. 716 ("Lee Tien is fundamentally misguided to believe that he can explain First Amendment coverage 'without appealing to a grand theoretical framework of First Amendment values.' If First Amendment coverage does not extend to all speech acts, then such a framework is at a minimum necessary in 
that it considers how far widely accepted forms and sources of reasoning can take us without relying on a theory of the Free Speech Clause.

The central widely accepted form of legal authority with regard to the Free Speech Clause is Supreme Court jurisprudence. Free Speech Clause cases have been a significant part of the Supreme Court's docket for almost a century. The number of cases, combined with the widely accepted common law approach to interpreting the Court's cases, makes for a fairly rich jurisprudence. Indeed, what is striking for my purposes is how broadly the Court has interpreted the scope of the Free Speech Clause, particularly in recent years, with the result that one can fairly answer most of the questions about algorithms without relying on any particular theories of the First Amendment. The ordinary lawyerly tools of case interpretation take us a fair distance.

\section{Expansion and Exceptions}

The history of the Supreme Court's First Amendment jurisprudence has been one of expansion. Libel and defamation were thought to be outside of the First Amendment's coverage until New York Times Co. v. Sullivan. ${ }^{30}$ Commercial advertising was considered to be beyond the scope of the First Amendment until Virginia State Board of Pharmacy v. Virginia Citizens Consumer Council, Inc. ${ }^{31}$ And that expansion of the scope of the Free Speech Clause has continued. In the IMS Health litigation, many (including the government and the First Circuit) contended that data miners' sale, transfer, and use of prescriberidentifying information was conduct, not speech. ${ }^{32}$ But the Supreme Court rejected this argument, emphasizing that "the creation and dissemination of information are speech within the meaning of the First Amendment." 33

order to provide the criteria by which to select the subset of speech acts that merit constitutional attention" (quoting L. Tien, Publishing Software as a Speech Act (2000) 15 Berkeley Technol. Law J. 629, 636)).

30 See 376 US 254, 268-9 (1964) (stating that although " $[\mathrm{r}]$ espondent relies heavily ... on statements of this Court to the effect that the Constitution does not protect libelous publications . . . libel can claim no talismanic immunity from constitutional limitations. It must be measured by standards that satisfy the First Amendment").

${ }^{31}$ See 425 US 748, 758, 770 (1976) (acknowledging that "in past decisions the Court has given some indication that commercial speech is unprotected," but holding that "commercial speech, like other varieties, is protected").

32 The First Circuit, for example, stated:

We say that the challenged elements of the Prescription Information Law principally regulate conduct because those provisions serve only to restrict the ability of data miners to aggregate, compile, and transfer information destined for narrowly defined commercial ends. In our view, this is a restriction on the conduct, not the speech, of the data miners. In other words, this is a situation in which information itself has become a commodity. The plaintiffs, who are in the business of harvesting, refining, and selling this commodity, ask us in essence to rule that because their product is information instead of, say, beef jerky, any regulation constitutes a restriction of speech. We think that such an interpretation stretches the fabric of the First Amendment beyond any rational measure.IMS Health Inc. v. Ayotte, 55 o F.3d 42, 52-3 (1st Cir. 2008), abrogated by Sorrell, above note 18 .

33 Sorrell, above note 18 , at 570 . The Court's discussion in Sorrell is illuminating:

[T]he United States Court of Appeals for the First Circuit has characterized prescriber-identifying information as a mere "commodity" with no greater entitlement to First Amendment protection than "beef jerky." In contrast the courts below concluded that a prohibition on the sale of prescriber-identifying information is a content-based rule akin to a ban on the sale of cookbooks, laboratory results, or train schedules.

This Court has held that the creation and dissemination of information are speech within the meaning of the First Amendment. Facts, after all, are the beginning point for much of the speech that is most essential to advance 
Not only has the Court expansively construed the coverage of the First Amendment (or, if you prefer, narrowed and eliminated assumed exceptions to First Amendment coverage), but it has also revealed an unwillingness to create new exceptions or construe existing categories of exceptions at a higher level of generality. This has been particularly clear in recent years. In United States v. Stevens, ${ }^{34}$ Brown v. Entertainment Merchants Association, ${ }^{35}$ and United States v. Alvarez, $3^{6}$ the Supreme Court emphatically rejected arguments in favor of broadening the categories that are outside First Amendment coverage. Indeed, the Alvarez plurality rejected understanding existing exceptions that focus on falsity (like fraud and defamation) as part of a more general exclusion of false statements of fact from First Amendment coverage. The flavor of the Court's approach toward exceptions is encapsulated in the following paragraph from Alvarez, quoting Stevens in the first two quotations and Brown in the last:

Although the First Amendment stands against any "freewheeling authority to declare new categories of speech outside the scope of the First Amendment," the Court has acknowledged that perhaps there exist "some categories of speech that have been historically unprotected ... but have not yet been specifically identified or discussed ... in our case law." Before exempting a category of speech from the normal prohibition on content-based restrictions, however, the Court must be presented with "persuasive evidence that a novel restriction on content is part of a long (if heretofore unrecognized) tradition of proscription." The Government has not demonstrated that false statements generally should constitute a new category of unprotected speech on this basis. ${ }^{37}$

I emphasize this backdrop because it highlights the Justices' apparent belief that their jurisprudence has laid out the relevant benchmarks for First Amendment coverage, subject only to "persuasive evidence that a novel restriction on content is part of a long (if heretofore unrecognized) tradition of proscription." ${ }^{8}$

\section{SUPREME COURT JURISPRUDENCE AND ALGORITHM-BASED DECISIONS}

I turn now to the Supreme Court cases most directly relevant to the coverage of algorithmbased outputs. That jurisprudence provides meaningful guidance. Brown is a good starting point. The Brown Court began its analysis of the legal issues in the case by stating flatly, "California correctly acknowledges that video games qualify for First Amendment

human knowledge and to conduct human affairs. There is thus a strong argument that prescriber-identifying information is speech for First Amendment purposes.Ibid. at 570 (internal citations omitted).

34 559 US $_{460}(2010)$

564 US 786 (2011).

$36 \quad 567$ US 709 (2012) (plurality opinion).

37 Ibid. at 722 (citations omitted) (quoting, respectively, Stevens, above note 34, at 473, and Brown, above note 35, at 792). The Alvarez plurality had earlier noted:

$[\mathrm{C}]$ ontent-based restrictions on speech have been permitted, as a general matter, only when confined to the few historic and traditional categories [of expression] long familiar to the bar ... Among these categories are advocacy intended, and likely, to incite imminent lawless action; obscenity; defamation; speech integral to criminal conduct; so-called "fighting words"; child pornography; fraud; true threats; and speech presenting some grave and imminent threat the government has the power to prevent, although a restriction under the last category is most difficult to sustain. These categories have a historical foundation in the Court's free speech tradition. The vast realm of free speech and thought always protected in our tradition can still thrive, and even be furthered, by adherence to those categories and rules.

Ibid. at 717-18 (citations and internal quotation marks omitted).

$3^{8}$ Brown, above note 35, at 792 . 
protection." 39 After noting that "it is difficult to distinguish politics from entertainment, and dangerous to try" and quoting from Winters v. New York, ${ }^{40}$ the Court concluded its discussion by stating categorically that "[v]ideo games communicate ideas - and even social messages through many familiar literary devices (such as characters, dialogue, plot, and music) and through features distinctive to the medium (such as the player's interaction with the virtual world). That suffices to confer First Amendment protection." ${ }^{41}$ In one short paragraph the Court concluded that video games are speech, period.

And there is a significant dog that didn't bark: the Court stated broadly that "video games" are covered by the First Amendment - not particular types of video games that entail certain kinds of interactions, but all video games..$^{22}$ The only possible limit implied by the Court's reasoning is that video games communicate ideas, but the Court's discussion makes it clear that it has a very low threshold for what constitutes such communication. Indeed, Justice Alito's concurrence argued at some length that video games were quite different from recognized forms of speech like books, ${ }^{43}$ prompting the majority to respond that "[e]ven if we can see in them "nothing of any possible value to society ... they are as much entitled to the protection of free speech as the best of literature." 44 It is certainly possible that a future Supreme Court could draw distinctions among video games, but nothing in Brown provides any support for such distinctions.

In Turner Broadcasting System, Inc. v. FCC (Turner I), ${ }^{45}$ confronting a First Amendment challenge to a statute that required cable operators to air local broadcast television stations, ${ }^{46}$ the Court flatly rejected the suggestion that this was ordinary economic regulation, and more specifically that cable operators were not engaged in speech for First Amendment purposes:

There can be no disagreement on an initial premise: Cable programmers and cable operators engage in and transmit speech, and they are entitled to the protection of the speech and press provisions of the First Amendment. Through "original programming or by exercising editorial discretion over which stations or programs to include in its repertoire," cable programmers and operators "see $[\mathrm{k}]$ to communicate messages on a wide variety of topics and in a wide variety of formats." 47

Ibid. at 790

40333 US $507,510(1948)$.

${ }^{41}$ Brown, above note 35, at 790. The entirety of the Court's discussion is as follows:

California correctly acknowledges that video games qualify for First Amendment protection. The Free Speech Clause exists principally to protect discourse on public matters, but we have long recognized that it is difficult to distinguish politics from entertainment, and dangerous to try. "Everyone is familiar with instances of propaganda through fiction. What is one man's amusement, teaches another's doctrine." Winters v. New York, 333 U.S. 507, 510 (1948). Like the protected books, plays, and movies that preceded them, video games communicate ideas - and even social messages - through many familiar literary devices (such as characters, dialogue, plot, and music) and through features distinctive to the medium (such as the player's interaction with the virtual world). That suffices to confer First Amendment protection.

Ibid.

$42 \quad$ Ibid.

43 See ibid. at 806 (Alito J. concurring in the judgment): "There are reasons to suspect that the experience of playing violent video games just might be very different from reading a book, listening to the radio, or watching a movie or a television show."

44 Ibid. at 796 n. 4 (quoting Winters, above note 40, at 510).

45 Above note 17 .

46 Cable Television Consumer Protection and Competition Act of 1992, Pub. L. 102-385, 106 Stat. 1460 (codified as amended in scattered sections of 47 USC).

47 Above note 17, at 636 (alteration in original; citation omitted; quoting City of Los Angeles v. Preferred Commc'ns, Inc., 476 US 488,494 (1986)). As the internal quotation indicates, the Court put forward the same test in Preferred Comme'ns. 
This language suggests two - and only two - elements for First Amendment coverage: first, that cable programmers and operators either create programming or choose what to air; and, second, that in doing so they seek to communicate messages on a variety of topics.

Turner I's focus on seeking to communicate messages is consistent with Supreme Court jurisprudence that has always treated substantive communication or self-expression as a necessary condition for the application of the First Amendment. ${ }^{4}$ In every case in which the Court has applied the First Amendment, abridgement of substantive communication has been the issue. ${ }^{49}$ Some of those abridgements are content-neutral, but the key is that they interfere with a person's or entity's ability to communicate content. The touchstone of the Court's First Amendment cases has always been that the underlying activity entails an expression of ideas, even if it is not "a narrow, succinctly articulable message." 50 Communication thus seems to require, at a minimum, a speaker who seeks to transmit some substantive message or messages ${ }^{51}$ to a listener who can recognize that message..$^{52}$ Thus,

48 See, e.g., Roth v. United States, 354 US 476, 484 (1957) (stating that the First Amendment "was fashioned to assure unfettered interchange of ideas for the bringing about of political and social changes desired by the people"); F. Schauer, Free Speech: A Philosophical Enquiry (Cambridge University Press, 1982), p. 94 ("Communication dominates all the arguments that would with any plausibility generate a Free Speech Principle”); S. G. Gey, Why Should the First Amendment Protect Government Speech When the Government Has Nothing to Say? (2010) 95 Iowa Law Rev. 1259, 1274 ("The Supreme Court has been very clear about the First Amendment requirement that speakers must engage in definitive communication before receiving constitutional protection for speech"); F. Schauer, Speech and "Speech" - Obscenity and "Obscenity": An Exercise in the Interpretation of Constitutional Language (1979) 67 Geo. Law J. 899, 920-1 ("The Court is saying that the communication of ideas is at once the essential first amendment purpose and the essential first amendment property. Without this purpose or property, activity is not protected by the first amendment").

One might reasonably ask what work "self-expression" is doing in the formulation in the text, on the assumption that self-expression is a substantive communication. Adding "self-expression" clarifies the inclusion of forms of expression that have been recognized as implicating the freedom of speech even though they arguably do not entail a clear substantive communication - in particular, recognized forms of art and symbolism. As the Supreme Court stated in Hurley, above note 28:

The protected expression that inheres in a parade is not limited to its banners and songs ... for the Constitution looks beyond written or spoken words as mediums of expression. Noting that "[s]ymbolism is a primitive but effective way of communicating ideas," our cases have recognized that the First Amendment shields such acts as saluting a flag (and refusing to do so), wearing an armband to protest a war, displaying a red flag, and even "[m]arching, walking or parading" in uniforms displaying the swastika. As some of these examples show, a narrow, succinctly articulable message is not a condition of constitutional protection, which if confined to expressions conveying a "particularized message," would never reach the unquestionably shielded painting of Jackson Pollock, music of Arnold Schoenberg, or Jabberwocky verse of Lewis Carroll.

Ibid., at 569 (citations omitted; quoting, respectively, W. Va. State Bd. of Educ. v. Barnette, 319 US 624, 632 (1943); Nat'l Socialist Party of Am. v. Village of Skokie, 432 US 43, 43 (1977) (per curiam); Spence v. Washington, 418 US 405, 411 (1974) (per curiam).

49 See, e.g., Rumsfeld v. Forum for Academic \& Institutional Rights, Inc., 547 US 47, 66 (2006) (noting that the Supreme Court has "extended First Amendment protection only to conduct that is inherently expressive"); Spence, above note 48, at 409-10 (finding that the display of an American flag with peace symbols was an activity "sufficiently imbued with elements of communication to fall within the scope of the First and Fourteenth Amendments").

$5 \circ$ Hurley, above note 28 , at 569 .

${ }^{51}$ In the remainder of this chapter, I will use the term "message" to refer to one or more messages for the sake of convenience and brevity.

52 See, e.g., K. Greenawalt, Speech, Crime, and the Uses of Language (Oxford University Press, 1989), p. 54 ("When the message is an aspect of what the actor is trying to do and is understood by the audience as such, we can say comfortably that the act communicates the message and that the free speech principle is relevant"); M. B. Nimmer, The Meaning of Symbolic Speech under the First Amendment (1973) 21 UCLA Law Rev. 29, 36 ("Whatever else may or may not be true of speech, as an irreducible minimum it must constitute a communication. That, in turn, implies both a communicator and a communicatee - a speaker and an audience"); T. Scanlon, A Theory of Freedom of Expression (1972) 1 Philos. Public Aff. 204, 206 (“[By] 'acts of 
in order to communicate, one must have a message that is sendable and receivable and that one actually chooses to send. ${ }^{53}$

Choosing to send a sendable and receivable substantive message may be necessary for First Amendment coverage, but that does not mean those criteria are sufficient for such coverage. Aren't they incomplete?

The answer may well be yes if we are considering the best definition of "speech" as a matter of first principles, but that is not my goal here. Such a foundational inquiry has felled many trees and is beyond the scope (and word limit) of this chapter.

Instead, in keeping with my focus on Supreme Court jurisprudence as the source of widely accepted guideposts, I will ask two questions that focus on possible incompleteness through the lens of the Supreme Court's jurisprudence. First, is relying solely on the minima identified above (choosing to send a sendable and receivable message) and the exceptions the Court has articulated inconsistent with the Court's First Amendment jurisprudence? Second, can we adopt one of the competing theories of the First Amendment in a way that keeps algorithm-based decisions out of First Amendment coverage but isn't significantly inconsistent with the Court's First Amendment jurisprudence? I will address the second question in the next section, but let me consider the first question here.

In posing this question, I am not asking whether the criteria I identify are complete for purposes of explicating the Supreme Court's approach to First Amendment coverage. They are not. The Court has articulated exceptions and qualifications applicable to, for example, expressive conduct, ${ }^{54}$ specific kinds of communications (such as speech integral to criminal conduct), ${ }^{55}$ and specific contexts (such as public forums). ${ }^{5}$ Rather, I am asking whether applying the criteria identified above plus the exceptions the Court has articulated would be inconsistent with some elements of the Court's jurisprudence. Are the criteria plus exceptions so incomplete that they do not adhere to some of the Court's rulings? This question may seem nonsensical insofar as it can be boiled down to "Is the Supreme Court's jurisprudence inconsistent with itself?" But the question makes sense in the context of a multi-member court often reaching incompletely theorized agreements that resolve specific disputes arising out of others' actions. ${ }^{57}$

The narrow answer is that the criteria and existing exceptions would not upend any existing Supreme Court jurisprudence. No Supreme Court holdings would be disturbed, no Supreme Court doctrines would have to be recast. ${ }^{8}$ The Court has never found

expression' ... I mean to include any act that is intended by its agent to communicate to one or more persons some proposition or attitude").

53 Some lower courts have issued opinions that may be in tension with this standard, but the Supreme Court has not done so, and my focus is on the Court's jurisprudence.

54 See, e.g., Rumsfeld, above note 49, at 65-6 (discussing what sorts of conduct are expressive and covered by the First Amendment).

55 See, e.g., Giboney v. Empire Storage \& Ice Co., 336 US 490, 498 (1949). For a recent list of First Amendment exceptions, see United States v. Alvarez, ${ }_{5} 67$ US 709 (2012) (including speech integral to criminal conduct, obscenity, and incitement, to name a few) (plurality opinion).

${ }^{6} 6$ See, e.g., Int'l Soc'y for Krishna Consciousness, Inc. v. Lee, 505 US 672, 678-85 (1992) (discussing the public forum doctrine).

57 See Sunstein, above note 25, p. $4^{8}$ (identifying incompletely theorized agreements as those "in which the most fundamental questions are left undecided”).

$5^{8}$ The same may not be true with regard to lower courts' jurisprudence. Most notably, lower courts have found that encyclopedias, how-to books, etc. are covered by the First Amendment, but have upheld liability for defective aeronautical charts without suggesting that such liability raised any First Amendment issues. See, e.g., Aetna Cas. ङ. Sur. Co. v. Jeppesen E. Co., 642 F.2d 339, 341-4 (9th Cir. 1981) (addressing liability for a defective aeronautical chart without discussing the First Amendment); cf. Brocklesby v. United States, 767 F.2d 1288, 1295 n. 9 (9th Cir. 
a substantive communication that was sendable, receivable, and actually sent to be outside First Amendment coverage unless it fell into one of the Court's articulated exceptions. The broader answer is that the breadth of First Amendment coverage suggested by these criteria might motivate us to find ways to narrow the application of First Amendment scrutiny, a topic I discuss later in this chapter.

To return to the criteria identified above: the Court's reasoning indicates that the First Amendment encompasses many algorithm-based manipulations. Consider a person who creates a billboard or webpage entitled "Our National Debt" that presents a running tally of the US national debt. ${ }^{59}$ The central feature of this billboard or webpage is simply a dollar figure generated by a computer running a program designed to measure the national debt. There need be no human involvement beyond creating the billboard or webpage and the program measuring the debt. Yet I don't think there is any real doubt that such a billboard or webpage would constitute speech in light of the Supreme Court's jurisprudence. It conveys a substantive message. Its running total of the national debt reflects a focus on and interest in the size of the national debt. It may not be clear to viewers exactly what the creator is trying to say about the national debt, but if nothing else the billboard or webpage communicates that the national debt is sufficiently important to merit this focus. ${ }^{60}$

Significantly, many communications that the Supreme Court treats as speech do not express a clear viewpoint, from a banner stating "BONG HiTS 4 JESUS" ${ }^{61}$ to almost every form of art. Given the ambiguities inherent in almost every piece of art, the Supreme Court's application of First Amendment protections to art precludes a requirement of a clear viewpoint or message. As the Court stated in Hurley v. Irish-American Gay, Lesbian \& Bisexual Group of Boston, Inc., "a narrow, succinctly articulable message is not a condition of constitutional protection, which if confined to expressions conveying a 'particularized message,' would never reach the unquestionably shielded painting of Jackson Pollock, music of Arnold Schoenberg, or Jabberwocky verse of Lewis Carroll." ${ }^{22}$ In Hurley the Supreme Judicial Court of Massachusetts held that the Boston St. Patrick's Day parade was not speech for First Amendment purposes because "it is impossible to discern any specific expressive

1985) (not reaching the First Amendment issue in a case involving an aeronautical chart because it was raised for the first time on appeal). It may be that aeronautical charts are best understood as falling into an exception that the Supreme Court has articulated. But it may well be that the Court's jurisprudence would treat these charts as speech for First Amendment purposes.

59 This is not a product of my imagination, of course. There is a well-known, billboard-sized "National Debt Clock" in Manhattan. Its central features are tallies of the national debt and the debt per American family. (The only text reads “Our National Debt," "Your Family Share," and “The National Debt Clock.") The clock simply follows an algorithm to calculate the national debt and then displays the result. There are also websites that perform similar functions. See, e.g., US Debt Clock, www.usdebtclock.org (providing continuously updated information on the national debt and related numbers - gross domestic product, credit card debt, etc.).

6o Note that the fact that the person or entity claiming to be engaged in speech does not create the underlying content is irrelevant for purposes of First Amendment coverage. See Hurley, above note 28, at 570 ("First Amendment protection [does not] require a speaker to generate, as an original matter, each item featured in the communication ... [T] he presentation of an edited compilation of speech generated by other persons is a staple of most newspapers' opinion pages, which, of course, fall squarely within the core of First Amendment security, as does even the simple selection of a paid noncommercial advertisement for inclusion in a daily paper" (citations omitted)); Turner I, above note 17, at 636 (finding that cable operators "engage in and transmit speech" by choosing channels to air); see also D. Sullivan, The New York Times Algorithm \& Why It Needs Government Regulation, Search Engine Land (July 15, 2010) http://searchengineland.com/regulating-the-new-york-times -46521 (analogizing Google to a newspaper).

61 See Morse v. Frederick, 551 US 393, 397 (2007). The Court treated the banner as speech under the First Amendment even though "the message on Frederick's banner is cryptic. It is no doubt offensive to some, perhaps amusing to others. To still others, it probably means nothing at all." Ibid. at 401.

62 Hurley, above note 28 , at 569 (citations omitted). 
purpose entitling the Parade to protection under the First Amendment." ${ }_{3}$ But the US Supreme Court, in reversing, unanimously rejected that argument, stating that "the parade does not consist of individual, unrelated segments that happen to be transmitted together for individual selection by members of the audience. Although each parade unit generally identifies itself, each is understood to contribute something to a common theme." ${ }^{4}$ The Court explained that, "[r]ather like a composer, the Council [running the parade] selects the expressive units of the parade from potential participants, and though the score may not produce a particularized message, each contingent's expression in the Council's eyes comports with what merits celebration on that day." 65

Imagine that a person sets up a bulletin board (an old-fashioned, physical bulletin board) on which she posts every article she finds that uses some specific words (say, "God is dead"66). She is not creating the articles; she is merely collecting articles written by others. And she is not editing beyond looking for the words; she is indiscriminately amassing all articles that use these words. But I think we would regard the bulletin board as speech for First Amendment purposes. The bulletin board would be communicating a substantive message to those who viewed it. Her viewpoint might not be clear (does she agree or disagree that God is dead?) but, if nothing else, the bulletin board tells her viewers that she thinks this topic is important enough to merit special attention, in the form of her bulletin board. Presenting all articles containing the words "God is dead" (or "Boston St. Patrick's Day Parade," for that matter) would not present a single clear message; rather, as in Turner I, it would constitute an exercise of editorial discretion through which the bulletin board editor sought to communicate a message about the importance of articles containing the words "God is dead."

Now imagine that the bulletin board editor belatedly discovers the Internet, and she transmogrifies her physical bulletin board into a virtual one. She performs computer searches for "God is dead" and posts links to all the articles that incorporate this phrase. Then she realizes that she can largely automate this process, so she creates a macro that lets her hit a single key to search the Web for the words "God is dead," and another macro that lets her hit a second key to upload onto her bulletin board any link that is not already posted. She begins to tire of performing these searches and realizes that a trained monkey could perform this task. Fortunately for her, she has a trained monkey, so she decides to let the monkey hit the two keys. The bulletin board editor then combines the operation into a single key for the monkey. Finally, after the monkey tires of all this typing, the bulletin board editor realizes that she can create a program that will automatically perform the search and post the relevant links without needing the monkey. Once the program starts, it continually searches the Web. In these steps from a physical bulletin board to an automated process, nothing relevant to free speech coverage under the Supreme Court's jurisprudence has changed. When it was physical, the editor's bulletin board communicated the importance to her of articles containing the words "God is dead." The same thing is communicated when the process is automated.

Similarly, consider the following progression: a time-pressed reporter realizes that she can write more articles if she uses some standard boilerplate to communicate information that arises repeatedly. She starts with cutting and pasting but finds that too laborious. So she

\footnotetext{
63 Irish-Am. Gay, Lesbian \& Bisexual Grp. of Bos. v. City of Boston, 636 NE.2d 1293, 1299 (Mass. 1994) (internal quotation marks omitted), rev'd sub. nom Hurley, above note 28.

64 Hurley, above note 28 , at 576.

65 Ibid. at 574 .

66 This example is not of my own making; I adapted it from elsewhere.
} 
creates macros for standard descriptions (for example, "Team A scored seven runs in the third inning, and team $B$ then scored nine runs in the third inning"). The macros become more complex, and utilize fancier language (for example, "in one inning the visitors notched an impressive 7 runs in the top half of the third inning, but the home team responded with a whopping nine runs in the bottom of the third"). The macros become so sophisticated that the reporter can create a template for virtually every outcome, and by adding some facts can stitch together blocks of text that produce a coherent article. Eventually, the reporter's computer skills become so advanced that she can input some basic data from a spreadsheet (for example, the box score from a baseball game) and run a macro that creates an entire article based on those facts. Finally she creates a macro that gathers those facts and writes the article, leaving her creative input entirely in the creation of the programs.

This is not a fanciful example. Algorithms produce what is sometimes called automated journalism - "the process of using software or algorithms to automatically generate news stories without human intervention - after the initial programming of the algorithm, of course." ${ }^{67}$ Publications such as Forbes, The Washington Post, Bloomberg News, and the Associated Press use such programs. ${ }^{68}$ Engineers, journalists, and computer linguists determine what facts and angles are of interest to them, compile a relevant vocabulary, and create algorithms to construct the articles. ${ }^{69}$ As with the example of the "God is dead" bulletin board, it is hard to see how any step in this progression crosses a line between speech and non-

67 A. Graefe, Guide to Automated Journalism, Columbia Journalism Review Tow Center Report (January 7, 2016), www.cjr.org/tow_center_reports/guide_to_automated_journalism.php. See also Narrative Science, What Is Natural Language Generation? https://narrativescience.com/what-is-nlg (“our software can look at your data and write a story from it, just like a human analyst would today").

In fact, the baseball example comes from an article quoting the following from a Narrative Science article:

Friona fell 10-8 to Boys Ranch in five innings on Monday at Friona despite racking up seven hits and eight runs. Friona was led by a flawless day at the dish by Hunter Sundre, who went $2-2$ against Boys Ranch pitching. Sundre singled in the third inning and tripled in the fourth inning ... Friona piled up the steals, swiping eight bags in all.

S. Levy, Can an Algorithm Write a Better News Story than a Human Reporter?, Wired (April 24, 2012), www.wired.com/gadgetlab/2012/04/can-an-algorithm-write-a-better-news-story-than-a-human-reporter/all (quoting a Narrative Science article). Not bad for a computer, eh?

68 See J. Peiser, The Rise of the Robot Reporter, New York Times (February 5, 2019) (noting that " $\mathrm{t}$ ] he system used by [Bloomberg News], Cyborg, is able to assist reporters in churning out thousands of articles on company earnings reports each quarter," and that "[t]he [Washington] Post has an in-house robot reporter called Heliograf"); WashPostPR, The Post's Heliograf and Modbot Technologies Take First Place in 2018 Global Biggies Awards, Washington Post (March 23, 2018) (noting that “[ $\mathrm{t}$ ]he Washington Post's Heliograf and ModBot technologies each took first place in the 2018 Global BIGGIES Awards which recognize best practices in big data and artificial intelligence products and strategies by media companies from around the world"); B. Mullin, The Associated Press Will Use Automated Writing To Cover the Minor Leagues (June 30, 2016), www.poynter.org /tech-tools/2016/the-associated-press-will-use-automated-writing-to-cover-the-minor-leagues; N. Sahota, A.I. May Have Written This Article. But Is That Such a Bad Thing?, Forbes (September 16, 2018), www.forbes.com/sites/ cognitiveworld/2018/og/16/did-ai-write-this-article; Graefe, above note 67.

69 See Graefe, above note 67 :

$[\mathrm{T}]$ he [automated journalism] software relies on a set of predefined rules that are specific to the problem at hand and which are usually derived from collaboration between engineers, journalists, and computer linguists. For example, within the domain of baseball, the software has to know that the team with the most runs - but not necessarily the most hits - wins the game. Furthermore, domain experts are necessary to define criteria of newsworthiness, according to which the algorithm looks for interesting events and ranks them by importance. Finally, computer linguists use sample texts to identify the underlying, semantic logic and translate them into a rule-based system that is capable of constructing sentences. If no such sample texts are available, trained journalists pre-write text modules and sample stories with the appropriate frames and language and adjust them to the official style guide of the publishing outlet. 
speech that arises from the Court's jurisprudence. The reporter/programmer is producing a substantive communication via editorial decisions. She designs the boilerplate and the mechanisms to put it together, and she does so in order to convey substantive information. Note that in all the steps of the progression, the reporter/programmer is relying to some degree on boilerplate that she did not create specially for the occasion. With each step she pushes more of her input to the front end (the creation of the boilerplate and the macros to input them), and leaves more implementation for the programs she has created. ${ }^{70}$

Most of the examples above involve webpages that focus on one particular area of interest. Does the analysis change without that focus? No. Suppose someone decides to create a website with the most important news of the moment, and the creator's substantive judgment is that importance is a function of popularity: the more popular an item is, the more important it is. So she creates an algorithm to identify news-oriented websites and to measure the popularity of items appearing on those websites, and the product of those algorithms yields an ever-changing set of links (in order of popularity) on her webpage. Above the links, her webpage says: "Here is the most important news, and by 'most important' I mean most popular." Her page would just be an automated collection of links, but under Turner I it would be speech.

Similarly, there are a number of search engines that are designed to be family-friendly by filtering out adult content, and in so doing communicate a substantive message about the desirability of deleting adult-oriented links. Or, in a different vein, an aggregator or search engine that promises to "prioritize links that have the most outrageous porn on the Web" is sending a substantive message that its users will receive, and that the Supreme Court's jurisprudence would treat as speech. And there is DuckDuckGo, a search engine that blocks spam as a proxy for relevance..$^{71}$ These search engines are not generating the linked-to content on their own, but the same is true of most of the examples above (and of the Drudge Report and other link aggregators).

That said, there are two distinctions between these search engines and most of the examples above that might seem relevant for First Amendment purposes. First, whereas one might surmise that the creators of the National Debt webpage and the "God is dead" link page are motivated by a particular viewpoint (even if one might guess incorrectly what that viewpoint was), it may be more difficult to ascribe a viewpoint to a spam-blocking search engine. Second, rather than collect items of interest in advance, it searches for them based on the user's preferences. These two points are closely related. Search engines respond to users'

This is not unique to articles, nor is it new. In 2008, a Russian publishing company programmed software to create a novel that was a variation on Leo Tolstoy's Anna Karenina, written in the style of Haruki Murakami (whose books were uploaded into the program). See I. Titova, Book Written by Computer Hits Shelves, St. Petersburg Times (Russ.) (January 22, 2008), www.sptimes.ru/story/24786. The publisher's chief editor explained: "Today publishing houses use different methods of the fastest possible book creation in this or that style meant for this or that readers' audience. Our program can help with that work." Ibid. He added: "However, the program can never become an author, like Photo[s] hop can never be Raphael." Ibid.

70 We have not yet, to my knowledge, reached that point with book chapters. Beep.

${ }^{71}$ See DuckDuckGo, https://duckduckgo.com. DuckDuckGo’s founder Gabriel Weinberg explained in an interview that " $[t]$ he main benefit you see right away is we try to get way better instant answers ... We're also way more aggressive with spam.” J. Vilches, Interview with DuckDuckGo Founder Gabriel Weinberg, TechSpot (August 21, 2012), www.techspot.com/article/559-gabriel-weinberg-interview/pagez.html. Weinberg added:

There's been a lot of the data that shows that initially when people click on content farm results, they actually like them because they often match their query exactly. But we believe that in the long run you won't like them, because they're often low quality content. So, that's a hard problem for search engines because a lot of the metrics they use for relevance show those results are very relevant, even though I think that they're not.

Ibid. 
queries and present information in light of those queries, and they do not screen for or focus on particular viewpoints.

As to the first point, under the prevailing jurisprudence, First Amendment coverage is not limited to speakers with a specific viewpoint, or even to speech of particular value. ${ }^{72}$ Magazines that publish articles on politics from every political perspective engage in what everyone would agree is speech, even if the editors themselves have no identifiable political views of their own. Regarding the second point, this seems to be a distinction without a difference for First Amendment purposes. Consider two platforms. The first compiles in advance a list of all the information sources that it judges to be family-friendly, and it lets users search among and select those sources in a variety of ways. The second platform does not compile anything in advance, but instead selects the information sources it judges to be family-friendly in response to users' queries. We can call the first platform a "family-friendly digital cable television" and the second platform a "family-friendly search engine." They are making the same judgments. The only difference is the users' browsing experience, for users who choose to browse rather than simply search. It is difficult to see how anything of constitutional significance could turn on this distinction. Even if it did, it is not clear which way the distinction would cut. Having an installed library of choices allows users to passively graze (or channel surf, in the digital cable context), whereas giving only the choice of search requires more active participation on the part of the user. The result is that the product of that search may be less reflective of the decisions of the platform and more reflective of the decisions of the user, but it is not clear whether that makes this product more or less clearly "speech." In any event, nothing seems to turn on the level of user participation, because both platforms are best understood as engaging in speech under the Court's First Amendment jurisprudence.

Is a search engine like Google different from a spam-blocking or family-friendly search engine under the Supreme Court's jurisprudence? I think not. Google states that search results are not Google's statements about your searches. ${ }^{73}$ But Google also notes that its searches emphasize quality. In 2017, in response to concerns about fake news, Google announced "Our latest quality improvements for Search" and stated that: "We've adjusted our signals to help surface more authoritative pages and demote low-quality content."74 And in 2011 it presented changes to its algorithms (known as Panda) as a means of returning more high-quality websites. ${ }^{75}$

What if we assume that Google (or another algorithm-based search engine) does not care about "quality," but instead only about relevance and usefulness for the user? Are Google's

72 See United States v. Stevens, 559 US 460, 479-80 (2010) ("Most of what we say to one another lacks 'religious, political, scientific, educational, journalistic, historical, or artistic value' (let alone serious value), but it is still sheltered from government regulation. Even '[w]holly neutral futilities ... come under the protection of free speech as fully as do Keats' poems or Donne’s sermons" (quoting Cohen v. California, 403 US 15, 25 (1971), emphasis in the original)).

73 See Search Using Autocomplete, Google, https://support.google.com/websearch/answer/10623o: "Search predictions aren't the answer to your search. They're also not statements by other people or Google about your search terms."

74 B. Gomes, Our Latest Quality Improvements for Search, Google (April 25, 2017), www.blog.google/products/ search/our-latest-quality-improvements-search. See also above notes 14 to 15 and accompanying text (on changes to YouTube's and Facebook's algorithms designed to substantively change what users see).

75 See M. Cutts, Another Step to Reward High-Quality Sites, Google Webmaster Central Blog (April 24, 2012), http:// googlewebmastercentral.blogspot.com/2012/o4/another-step-to-reward-high-quality.html ("The goal of many of our ranking changes is to help searchers find sites that provide a great user experience and fulfill their information needs. We also want the 'good guys' making great sites for users, not just algorithms, to see their effort rewarded. To that end we've launched Panda changes that successfully returned higher-quality sites in search results”). 
algorithm-based outputs based on its understanding of relevance and usefulness speech under the Supreme Court's jurisprudence? Yes. Google is making all sorts of judgments in determining what its users want. ${ }^{76}$ There is a reasonable argument against this conclusion, flowing from the position that editing and transmitting information based on what users want is not an expression of the speaker's own desires and thus is not real speech. As I discuss in the next section, however, the Supreme Court has not adopted that position and its jurisprudence is not consistent with it.

Many algorithm-based outputs will not constitute speech under this jurisprudence because they are not sending a substantive message. Transmission Control Protocol and Internet Protocol (often referred to as TCP/IP) route information through the Internet, but its creators are not communicating a substantive message in doing so. ${ }^{77}$ But when people create algorithms in order to selectively present information based on its perceived importance, value, or relevance, Turner I indicates that they are speakers for purposes of the First Amendment (or the Supreme Court's jurisprudence, at any rate). Nothing in the Court's jurisprudence supports the proposition that reliance on algorithms transforms speech into non-speech. The touchstone is sending a substantive message, and such a message can be sent with or without relying on algorithms. ${ }^{78}$

One final note: many trees were felled before Brown was decided, as courts and commentators debated whether video games constituted speech for First Amendment purposes. ${ }^{79}$ And

$7^{6}$ For an example of Google debating how to improve searches for its customers, see Google, Search Quality Meeting: Spelling for Long Queries (Annotated), YouTube (March 12, 2012), www.youtube.com/watch? $v=J$ tRJXnXgE-A (showing Google's search quality team deliberating on algorithmic decisions during a meeting held on December 1, 2011).

77 For an explanation of the TCP/IP protocols, see J. Strickland, How Does the Internet Work?, HowStuffWorks (May 7, 2010), http://computer.howstuffworks.com/internet/basics/internetı.htm.

$7^{8}$ Tim Wu has argued that under the prevailing jurisprudence, the key inquiry is whether the alleged speaker adopts the information it provides as its own. See T. Wu, Machine Speech (2013) 161 Univ. Pa. Law Rev. 1498, 1530 ("Neither the newspaper nor cable operator cases support the idea that the First Amendment protects something like an index, as opposed to content adopted or selected by the speaker as its own. It is that step - the adoption of information, as a publisher, as opposed to merely pointing the user to it - that marks the difference"). I agree with $\mathrm{Wu}$ that the Supreme Court's jurisprudence does not support treating an unedited index as speech, but I do not think the line he articulates arises from, or is consistent with, that jurisprudence. The Court in Turner $I$, above note 17 , held that cable operators engage in speech because of their editing, without any suggestion that cable operators do, or need to, adopt as their own the communications of the channels they carry. See above note 17 , at 636 ("Through ... 'exercising editorial discretion over which stations ... to include in its repertoire,' cable ... operators 'see $[\mathrm{k}]$ to communicate messages' ..."). See also Hurley, above note 28 , at 570 (noting that "even the simple selection of a paid noncommercial advertisement for inclusion in a daily paper" "fall[s] squarely within the core of First Amendment security"). Under Turner I, engaging in substantive editing sends a message and thus triggers application of the First Amendment - no adoption or endorsement of the carried programming is needed. To modify Wu's example, no one who watches Fox News, MSNBC, or any other cable channel addressing topic $X$ says, "Look what my cable operator said about $X$ yesterday," or, "It was interesting what my cable operator had to say about X." Nonetheless, the First Amendment encompasses the cable operator's selection of channels. See Wu, ibid., p. 1528 (using the quoted language to illustrate the line he sees between speech and non-speech in the jurisprudence relevant to search engines).

79 See, e.g., Interactive Digital Software Ass'n v. St. Louis County, 200 F. Supp. 2d 1126, 1133-4 (ED Mo. 2002) (finding that video games are not speech for First Amendment purposes), rev'd, 329 F.3d 954 (8th Cir. 2003); America's Best Family Showplace Corp. v. City of New York, 536 F. Supp. 170, 174 (EDNY 1982) (same); M. J. Blitz, A First Amendment for Second Life: What Virtual Worlds Mean for the Law of Video Games (2009) 11 Vand. J. Ent. Technol. Law 779, 785 (arguing that even non-narrative video games and other "communication-free forms of electronic imagery" should be "staunchly protected"); T. R. Day and R. C. W. Hall, Déjà Vu: From Comic Books to Video Games: Legislative Reliance on "Soft Science” to Protect against Uncertain Societal Harm Linked to Violence v. the First Amendment (2010) 89 Or. Law Rev. 415, 450 (arguing that video games are "no less deserving of First Amendment protection than movies, works of art, and literature"); 
yet the Court treated this as a question with an obvious answer. Indeed, part of what is so striking about the opinion is how easy the Court found the answer to be. ${ }^{80}$

Does this mean that heightened scrutiny will apply to almost every regulation of entities that produce words via algorithm? No. The algorithm must send a substantive message. Algorithms that are designed to speed transmission, or make a network operate more efficiently, are not sending any substantive message. Your landline telephone (remember those?) might work better if the telephone company installed algorithms that reduce background noise, but the telephone company has not substantively communicated anything by doing so. ${ }^{81}$ One could reject this limitation, but such a rejection would constitute a significant remaking of First Amendment jurisprudence.

\section{PRODUCING A DIFFERENT RESULT}

As I noted above, there are a host of competing conceptions of the Free Speech Clause, none of which has been widely accepted as explaining or driving First Amendment doctrine. But let me now ask whether adopting one of the competing theories of the First Amendment would produce a different result without upending existing case law. More broadly, how difficult would it be to craft a coherent exception to the prevailing First Amendment jurisprudence such that algorithm-based decisions, or search results more specifically, would not be encompassed by the First Amendment but most of the remaining First Amendment jurisprudence would remain? This is different from asking whether, in the first instance, any theory of the First Amendment would exclude algorithm-based decisions from coverage. The answer to that question is yes. That is, we could rely on a particular conception of the First Amendment that would radically rethink the Supreme Court's existing approach in ways that would exclude search engine results and much else. We could, for example, limit "the freedom of speech" in the First Amendment to core political speech, or speech that directly promotes a meaningfully constrained notion of democratic deliberation or self-government, and thereby exclude search engine results, as a category, from the ambit of the First Amendment. ${ }^{82}$ We would also exclude most forms of art, however. ${ }^{83}$ My question in this section is, without radically changing our First Amendment

P. M. Garry, Defining Speech in an Entertainment Age: The Case of First Amendment Protection for Video Games (2004) 57 SMU Law Rev. 101, 122 (arguing against full First Amendment protection for video games); P. E. Salamanca, Video Games as a Protected Form of Expression (2005) 40 Ga. Law Rev. 153, 194-205 (arguing against viewing video games as unprotected speech); K. W. Saunders, Regulating Youth Access to Violent Video Games: Three Responses to First Amendment Concerns (2003) 51 Mich. St. Law Rev. 101-5 (arguing that video games are non-communicative and not speech for First Amendment purposes); A. Ventry III, Note, Application of the First Amendment to Violent and Nonviolent Video Games (2004) 20 Ga. St. Univ. Law Rev. 1129, 1131 (arguing that "courts should apply a case-by-case approach in determining whether video games are constitutionally protected speech instead of deciding conclusively that all video games are (or are not) protected speech").

8० See above notes 39-44 and accompanying text; see also Sorrell, above note 18, at 557: "Speech in aid of pharmaceutical marketing ... is a form of expression protected by the Free Speech Clause of the First Amendment."

${ }^{81}$ See S. M. Benjamin, Transmitting, Editing, and Communicating: Determining What "The Freedom of Speech" Encompasses (2011) 6o Duke Law J. 1673, 1686.

82 See, e.g., Bork, above note 23, p. 20 ("Constitutional protection should be accorded only to speech that is explicitly political").

83 We could avoid such a result if we adopted a very broad definition of "core political speech," "democratic deliberation," or "self-government," but then we would end up back where we started. As Frederick Schauer has noted: 
jurisprudence, how easy would it be to exclude algorithm-based decisions, or search engine results more specifically?

\section{Relying on Particular Theories of the First Amendment}

The most obvious possibility would be to focus the First Amendment analysis on individuals. This could lead to a suggestion that communications by corporations do not constitute speech. But newspapers and magazines are owned by corporations, and a revamping of the First Amendment to exclude those publications as speech would be a radical departure from our existing jurisprudence.

One might instead try to exclude from First Amendment coverage speech that a corporation makes purely for its own benefit. The problem is that it is difficult to come up with any articulation of speech in a corporation's interest that would exclude algorithm-based decisions, or more specifically search engine results, without also excluding newspapers and magazines. A distinction based on speech that is in a corporation's interest fails to distinguish newspapers and magazines. The same applies for excluding speech that is aimed solely at increasing a corporation's value. Indeed, for a newspaper or magazine owner who is a faithful agent, with shareholders who want the highest possible return on their investment, presumably all the owner's actions would be undertaken in order to maximize shareholder value. Simply stated, search results are in the search engine's interests in the same way that compelling content is in the interest of any conveyor of content, whether newspaper, political website, or porn website.

A more conventional line would distinguish commercial speech. A number of theorists have argued for the exclusion of commercial speech from First Amendment coverage. ${ }^{84}$ This would be a fairly significant reworking of First Amendment jurisprudence. ${ }^{85}$ Excluding commercial speech also would not affect most algorithm-based decisions. It would apply to search engines' (and newspapers') advertisements, but most search engine results are not paid advertisements. ${ }^{86}$

A different way of emphasizing individuals would focus on their expression. Theories focused on self-expression, for example, emphasize that it is an individual's self-expression that matters, and autonomy-based theories similarly emphasize individual autonomy. The problem is that many algorithm-based decisions similarly involve the creator's self-expression and autonomy. Depending on the algorithm, algorithm-based decisions may well constitute

Theories based on self-government or democratic deliberation have a hard time explaining why (except as mistakes, of course) the doctrine now covers pornography, commercial advertising, and art, inter alia none of which has much to do with political deliberation or self-governance, except under such an attenuated definition of "political" that the justification's core loses much of its power.

Schauer, above note 4 , p. 1785 .

84 See, e.g., C. Edwin Baker, Commercial Speech: A Problem in the Theory of Freedom (1976) 62 Iowa. Law Rev. 1, 3 ("[G]iven the existing form of social and economic relationships in the United States, a complete denial of first amendment protection for commercial speech is not only consistent with, but is required by, first amendment theory"); C. R. Sunstein, Democracy and the Problem of Free Speech (Free Press, 1993), pp. 123, 127 (arguing for little protection of advertising because it does not contribute to democratic deliberation).

85 See, e.g., Cent. Hudson Gas \& Elec. Corp. v. Pub. Serv. Comm'n, 447 US 557, 561 (1980) ("The First Amendment ... protects commercial speech from unwarranted governmental regulation”); 44 Liquormart, Inc. v. Rhode Island, 517 US 484 (1996) (applying First Amendment scrutiny to the regulation of commercial advertisements).

86 Some early search engines relied heavily on payments in determining what to present and where to present it. One of Google's selling points was that it used page-rank algorithms and that what little paid content it had was clearly demarcated as such. Newer search engines have followed Google's lead. Google and its newer competitors realized that they could attract users by prioritizing relevant quality websites, and make more money from advertisers relegated to the side because of the large number of people who would be attracted by the promise of search results containing relevant websites. 
self-expression, enhance autonomy, and contain meaningful thought. The algorithm is simply a means to gather relevant information, but the creator chooses what to gather. The person who creates the National Debt webpage, or the "God is dead" link page, is expressing a view about the importance of those topics. Or consider a webpage that uses an algorithm to amass links to articles with the words "Trump sucks" or "Clinton sucks." These webpages require less curating than does the Drudge Report, but all of them reflect autonomous expression.

Search engines are a closer question, but a definition of self-expression that excludes them would be a fairly crabbed one. Start with a search engine that focuses on family-friendly material (or, if you prefer, porn). This seems to encode autonomous expression - "We value family-friendly material/porn, and we want to make it easier for you to find it." Of course, the creators' actual motivation might be more base - most obviously: "We just want to make money." But that may well be the true motivation for many newspapers and magazines, and many artists, for that matter (I'm looking at you, Jeff Koons). And because theories of selfexpression and individual autonomy treat art as squarely within their understanding of speech, those who emphasize self-expression or autonomy usually do not focus on the speaker's subjective motivation, but instead on the apparent expression reflected in the message. In this case there is an apparent expression, as I noted above.

It is a very small step from that expression to DuckDuckGo's expression. Instead of "We want to avoid/find porn, and we want to make it easier for you to avoid/find it," the expression would be "We want to avoid spam, and we want to make it easier for you to avoid it." And it is then another small step to Google's expression. As I noted above, Google, too, articulates quality as its goal. But even if we credit only its focus on relevance, substituting "relevant" for "quality" in the expression does not make it any less of an expression. In all cases, the algorithm creators are expressing their views about what they value.

Perhaps Google in particular is different, insofar as its message is not so much "We value relevant websites" but more like "We select for you what you want." In the latter formulation, Google arguably is not expressing its own preferences so much as it is indicating that it wants to satisfy ours.

Differentiating Google for purposes of First Amendment coverage based on its catering to users' interests would be a significant shift in First Amendment jurisprudence, as publications and editors that frankly focus on their viewers' or readers' interests would be unprotected. It has not mattered in the past whether a magazine owner (or cable operator) was merely responding to a market opportunity or was expressing its own subjective preferences, but now that difference would be dispositive. If we define unprotected speech to include speech that responds to public demand, only the few publications that push their ideas regardless of public interest ${ }^{87}$ would be speakers, and that would upend most First Amendment law.

Beyond that, this would be a mighty thin reed on which to rest a distinction. We can recharacterize Google's position as "Our preference is to select for you what we believe you find valuable." If we substitute "is" for "you find," or change the locution to "we believe you should find valuable," there is clearly expression. So we would be putting an enormous amount of weight on the creators' articulation as focused on what others want.

Articulating one's goal in terms of serving others is still an exercise of autonomy and a form of self-expression. "What makes you happy makes me happy" is an expression of self - one that looks to another for one's happiness, but an expression of personal motivation nonetheless. In

87 We usually call these "vanity publications." 
the same way, the artist who proclaims that she is guided by what her viewers want has still made a self-defining and art-defining statement. ${ }^{88}$

It also bears noting that decisions about what users want are analogous to the decisions of cable operators that the Court found to be speech in Turner I. In their briefs, the cable operators stressed that a key consideration in choosing what channels to include was what they thought their customers wanted. ${ }^{89}$ Indeed, a major element of the cable operators' argument that there was no sufficient justification for the statute was their assertion that cable operators would be guided by viewer interest and thus would air the most popular channels whether or not they had an ownership interest in them. ${ }^{90}$ The cable operators, in choosing what channels to air, were engaged in editing, on whatever substantive basis they chose, and those editorial decisions constituted speech. The cable operators claimed they were editing in light of their sense of their customers' wishes, and Google is doing the exact same thing.

A different approach would involve a focus on the audience. Some Supreme Court opinions and some commentators have emphasized the importance of listeners and viewers having access to a wide range of views. ${ }^{91}$ But a "right to receive information" is articulated as an addition to the rights of speakers, as opposed to a substitute for them, and so would not limit the treatment of algorithm-based decisions as speech..$^{92}$ It does bear noting, though, that a focus on the rights of the audience might buttress the position of some algorithm-based outputs - in particular, search engines. One way of conceptualizing the rights of listeners and viewers is as a right to unencumbered access to information. ${ }^{93}$ Such a conceptualization would lend support to the treatment of an individual's search results as part of the information that is encompassed by the Free Speech Clause. A different conceptualization would interpret the rights of listeners and viewers as justifying government regulation of information providers, but application of such arguments to exclude information providers from coverage

88 Cf. The Kinks, Give the People What They Want (Arista Records, 1981).

89 See, e.g., Reply Brief for Appellants Turner Broad. Sys., Inc. at 19-20, Tumer I, above note 17, (No. 93-44), 1993 WL 664649 ("A cable operator's very raison d'être is to choose from among the enormous variety of sources of video programming available in order to put together a package of programming that will be appealing to television viewers"); Reply Brief for Appellants Discovery Commc'ns, Inc. and the Learning Channel, Inc. at 6, Turner I, above note 17, (No. 93-44), 1993 WL 664652 (emphasizing the role of market forces in cable operators' choices of which channels to carry).

$9 \circ$ Nothing in the Court's opinion suggests that any aspect of First Amendment coverage turned on the degree to which a cable operator chose channels purely on mechanistic measures of popularity.

${ }^{91}$ See, e.g., First Nat'l Bank v. Bellotti, above note 28, at 783 (noting that the First Amendment affords the public "access to discussion, debate, and the dissemination of information and ideas"); Va. State Bd. of Pharmacy, above note 31, at 757 (stating that the "freedom of speech "necessarily protects the right to receive"); Kleindienst v. Mandel, 408 US 753, 762 (1972) ("In a variety of contexts this Court has referred to a First Amendment right to receive information and ideas" (internal quotation marks omitted)); Stanley v. Georgia, 394 US 557, 564 (1969) ("It is now well established that the Constitution protects the right to receive information and ideas"); Griswold v. Connecticut, 381 US 479, 482 (1965) (stating that the freedom of speech includes "the right to receive"); see also T. I. Emerson, Legal Foundations of the Right to Know (1976) Wash. Univ. Law Q. 1, 2 ("It is clear at the outset that the right to know fits readily into the first amendment..."); T. Scanlon, A Theory of Freedom of Expression (1972) 1 Philos. Public Aff. 204 (arguing that the First Amendment protects listeners' access to information and viewpoints and thereby protects autonomy).

92 See Va. State Bd. of Pharmacy, above note 31, at 756 ("Freedom of speech presupposes a willing speaker. But where a speaker exists, ... the protection afforded is to the communication, to its source and to its recipients both").

93 See, e.g., ibid.; Sorrell, above note 18, at 577 ("[T] he fear that people would make bad decisions if given truthful information cannot justify content-based burdens on speech. The First Amendment directs us to be especially skeptical of regulations that seek to keep people in the dark for what the government perceives to be their own good" (citations and internal quotation marks omitted)); Edenfield v. Fane, 507 US 761, 767 (1993) ("The commercial marketplace, like other spheres of our social and cultural life, provides a forum where ideas and information flourish.... [T]he general rule is that the speaker and the audience, not the government, assess the value of the information presented"). 
by the Free Speech Clause would be a radical change in First Amendment jurisprudence. ${ }^{94}$ For better or worse, the Supreme Court's jurisprudence has decisively rejected this vision. ${ }^{95}$

Yet another direction would focus on the government's purpose or motive in enacting a particular regulation. Some commentators (including then-professor Elena Kagan) have suggested that First Amendment coverage should turn on the government's purpose or motive, such that an economic motive should not trigger First Amendment coverage but a censorious motive should. ${ }^{96}$ Whatever the merits of this approach, and whatever its application to algorithm-based outputs, it is inconsistent with a significant number of Supreme Court cases that applied the First Amendment despite the fact that the underlying regulation had an economic motive. ${ }^{97}$

There are of course other theories of the First Amendment, but all would either draw arbitrary lines or exclude much that we currently consider to be speech.

94 See Red Lion, above note 27 , at 390 (suggesting that the freedom of speech includes "the right of the public to receive suitable access to social, political, esthetic, moral, and other ideas and experiences”); J. A. Barron, Access to the Press - a New First Amendment Right (1967) 80 Harv. Law Rev. 1641, 1666 ("It is to be hoped that an awareness of the listener's interest in broadcasting will lead to an equivalent concern for the reader's stake in the press, and that first amendment recognition will be given to a right of access for the protection of the reader, the listener, and the viewer").

95 See, e.g., Pac. Gas \& Elec. Co. v. Pub. Utils. Comm'n, 475 US 1, 4, 20-1 (1986) (plurality opinion) (holding that a state utility commission could not constitutionally compel a private utility company to include in its billing envelopes materials produced by an adverse group); Miami Herald Pub. Co. v. Tornillo, 418 US 241, 258 (1974) (holding unconstitutional a state statute guaranteeing political candidates media access to respond to criticism). Indeed, the Supreme Court has largely abandoned its intimation in Red Lion that the First Amendment empowers the government to give access rights to listeners and viewers. As it turns out, broadcasting is the only area that the Court has treated as justifying a right of access - and even there, the Court has held that broadcasters have First Amendment rights (just diminished ones).

${ }^{6}$ See, e.g., E. Kagan, Private Speech, Public Purpose: The Role of Governmental Motive in First Amendment Doctrine (1996) 63 Univ. Chi. Law Rev. 413, 414 (arguing "that First Amendment law, as developed by the Supreme Court over the past several decades, has as its primary, though unstated, object the discovery of improper governmental motives"); J. Rubenfeld, The First Amendment's Purpose (2001) 53 Stan. Law Rev. $767,775-9$ (asserting the centrality of a law's purpose in determining the appropriate application of the First Amendment).

97 See Sorrell, above note 18, at 567 (applying First Amendment scrutiny to a regulation motivated by economic considerations and stating that, "[w]hile the burdened speech results from an economic motive, so too does a great deal of vital expression”); United States v. United Foods, Inc., 533 US 405, 408, 417 (2001) (applying First Amendment scrutiny to an agricultural assessment requirement on the grounds that it compelled mushroom handlers to fund speech with which they disagreed); Turner I, above note 17, at 638 (applying First Amendment scrutiny to legislation while also finding that "Congress' overriding objective in enacting [a law requiring cable carriage of local television broadcasters] was ... to preserve access to free television programming for the 40 percent of Americans without cable"); Members of City Council of Los Angeles v. Taxpayers for Vincent, 466 US 789, 804 (1984) (applying First Amendment to an ordinance even though " $t \mathrm{t}]$ he text of the ordinance is neutral," and "there is not even a hint of bias or censorship in the City's enactment or enforcement of this ordinance"); Minneapolis Star \& Tribune Co. v. Minnesota Comm'r of Revenue, 460 US 575, 592 (1983) ("We have long recognized that even regulations aimed at proper governmental concerns can restrict unduly the exercise of rights protected by the First Amendment"). The Supreme Court has also squarely rejected the more modest argument that, within the universe of First Amendment coverage, strict scrutiny for content-based regulations should not apply if the government has "[i]nnocent motives." Reed v. Town of Gilbert, Ariz., 135 S. Ct. 2218, 2229 (2015) ("Innocent motives do not eliminate the danger of censorship presented by a facially contentbased statute"); ibid. at 2228 ("A law that is content based on its face is subject to strict scrutiny regardless of the government's benign motive, content-neutral justification, or lack of 'animus toward the ideas contained' in the regulated speech" (internal citation omitted)). 


\section{A Useful Algorithm-Based Line}

As the discussion above indicates, crafting a First Amendment exclusion only for algorithm-based decisions would be arbitrary, and crafting a non-arbitrary category that excludes algorithm-based decisions would exclude much of what we regard as speech and thus significantly change our jurisprudence. Because of the similarity of algorithmbased decisions to communications that are clearly speech under the prevailing Supreme Court jurisprudence, there do not appear to be any principled distinctions that would leave algorithm-based decisions uncovered without upending significant aspects of that jurisprudence. But a different line is tenable and might do significant work in the future even if it would not do any at present: excluding outputs that do not reflect human decision-making.

A key element of the discussion so far is that there is a human mind behind all the algorithms. The fact that an algorithm is involved does not mean that a machine is doing the talking. Individuals are sending a substantive message in such a way that others can receive it. The point of the discussion so far is that adding algorithms does not change the Free Speech Clause analysis when humans are still creating the template.

But what happens to the analysis if humans are no longer meaningfully creating the message? That is, how should we analyze a situation in which artificial intelligence (AI) has developed to the point that a set of algorithms have freed themselves from human direction such that the product of the algorithms does not reflect human decision-making about what to communicate?

Computer scientists have developed programs that engage in massive data analysis that would take humans eons to complete, but those programs do not exercise any independent judgment. Similarly, the outputs of AI may be inscrutable, but that does mean that the machines generating those outputs have volition; opacity and independent judgment are two quite different things.

Some programs use random variation as a means of experimentation and possible adaptation. For instance, some programs use not only formulas but also some prescribed points of randomness to allow the computer program to produce a range of outcomes. A particularly enjoyable example is The Nietzsche Family Circus, a webpage which, with each hit of the "refresh" button, pairs a randomized Family Circus cartoon with a randomized Friedrich Nietzsche quote. ${ }^{9}$ Whatever meaning we find in this randomized process and its results is due to the program's clever (human) designer and our reactions to that design. After all, the same effect could be achieved (à la John Cage) by throwing grains of rice emblazoned (in very tiny letters) with Nietzsche quotations into the air above a checkerboard of Family Circus cartoons. There would likely be all sorts of interesting pairings, but we wouldn't attribute any agency in generating a message to the grains of rice.

A bit closer to home, programmers have created programs that generate random papers, at least one of which was accepted at a conference. ${ }^{99}$ But the random processes are not crafting

$9^{8}$ See Nietzsche Family Circus, www.nietzschefamilycircus.com/.

99 See, e.g., SCIgen - An Automatic CS Paper Generator, http://pdos.csail.mit.edu/scigen/\#relwork ("SCIgen is a program that generates random Computer Science research papers, including graphs, figures, and citations. It uses a hand-written context-free grammar to form all elements of the papers. Our aim here is to maximize amusement, rather than coherence" (emphasis omitted)); timothy, Randomly Generated Paper Accepted to Conference, Slashdot (April 13, 2005), http://entertainment.slashdot.org/story/05/04/13/1723206/randomlygenerated-paper-accepted-to-conference ("Some students at MIT wrote a program called SCIgen ... [and] one of their randomly generated paper[s] was accepted to [the 2005 World Multiconference on Systemics, Cybernetics, and Informatics]. Now they are accepting donation $[s]$ to fund their trip to the conference and give a randomly generated talk" (emphasis omitted)). 
substantive messages. ${ }^{100}$ Humans are crafting messages about academic standards and are employing randomness to do so. As the webpage of the Postmodernism Generator (which "creates realistic-looking but meaningless academic papers about postmodernism, poststructuralism and similar subjects") notes: "The papers produced are perfectly grammatically correct and read as if written by a human being; any meaning found in them, however, is purely coincidental." ${ }^{101}$ That is the substantive message, and it derives from decisions made by the human designers. The programs are fun precisely because we may ascribe meaning even to the results of random processes, whether random words or random raindrops on the pavement. Those raindrops have not in fact sent us a substantive message; we just choose to read something into the random picture they create.

Other programs use randomness for purposes of experimentation and adaptation toward a prescribed goal. Programmers have, for example, created programs that break into multiple offshoots, each having some decision points at which randomness comes into play and thus produces different outcomes. The program itself (or the programmer) then determines which of these permutations comes closest to achieving a prescribed goal (modeling past stock movements and predicting future stock movements are popular, as is winning at Go), and there can be multiple generations of such permutations, resulting in unguided adaptation toward a goal. This is also how some computer viruses work: they are programmed to use randomness at key points (often in response to the host program's defenses), in the hope that some versions of the virus will become more effective at propagating and achieving the programmer's goal. This is different from random raindrops on the pavement, because once we see what adaptation best achieves our goal of predicting stock prices or winning games of Go, we can choose it. This applies to adaptations we can identify (for example, "add yesterday's closing price of Facebook's stock to the previous day's rainfall in Seattle and divide by the previous night's number of viewers of the CBS Evening News") and to adaptations that are inscrutable to us, such that we do not understand how they generated their outputs. That is the story of AlphaGo, for example. ${ }^{102}$ But the adaptation and resulting output is not creating and communicating a substantive message on its own. We have designed the goal and the means to achieve it. We find the adaptation useful because it moves us toward the goal that we have chosen. We are supplying the volition and all the meaning. ${ }^{103}$

That said, AI could cross, or at least blur, this line. ${ }^{104}$ Imagine that AI advances to such a level that machines are in some meaningful sense choosing their own goals and what substantive communications will achieve those goals. Just as a machine may at some point

100 The whole point is that humans are prone to find messages and meaning even in random collections of words and numbers.

101 Postmodernism Generator, http://pagen12.com/iphone/pomo/. The creators of The Postmodern Generator added the elegantly understated caveat that "submitting generated texts to journals or academic courses is not recommended." Ibid.

This is different from the process used by automated journalism programs (see above notes $67-9$ and accompanying text) because those entities do try to communicate substantive messages with their choice of words, just as a human author does. A writer (or law professor) who relies on a template or cuts and pastes boilerplate into her article does so in order to communicate a substantive message (just one that can be communicated via off-the-shelf language), and so too automated journalism programs utilize templates and boilerplate in order to communicate information.

102 See J. X. Chen, The Evolution of Computing: AlphaGo, Computing in Science E Engineering (July/August 2016).

103 To put the matter a bit differently, telling the world that this formula, or the price of tea in China, predicts the stock market's movements is a form of substantive communication. But that fact does not mean that the formula, or the price of tea in China, is independently communicating anything.

104 See, e.g., S. Chopra and L. F. White, A Legal Theory for Autonomous Artificial Agents (2011) (extending legal principles to the unique challenges posed by the evolution and increasing sophistication of artificial agents); Collins and Skover, above note 12 (discussing speech rights for robots); Massaro et al., above note 12 (same). 
satisfy the Turing test, ${ }^{105}$ it may at some point demonstrate a level of choice or volition that is indistinguishable from that of humans. At that point, we might say that the connection to the human creators is sufficiently attenuated that the results no longer reflect humans' decisions about how to determine what to produce, such that there is no longer a human sending a substantive message. No human would be communicating anything. Extending the First Amendment to messages produced by this AI would raise the specter that we would be treating the products of machines like those of human minds. We could then say that "speech" was truly created (and not just transmitted, or aided) by a machine. ${ }^{106}$

\section{CONCLUSION}

In this chapter I have attempted to take seriously both widely accepted sources and forms of reasoning and concerns about expansion of the application of the First Amendment. Consistent with that focus, I have considered how those widely accepted sources (in particular Supreme Court jurisprudence) would apply to First Amendment coverage of algorithm-based decisions and whether we can exclude such decisions from the First Amendment without radically revamping First Amendment jurisprudence.

Those worried about the Free Speech Clause expanding too far, particularly with regard to algorithm-based decision-making (or maybe just Internet searches), might find this unacceptable. If drawing non-arbitrary lines that do not radically reorient First Amendment jurisprudence provides protections for algorithm-based outputs, then perhaps we should be willing to draw arbitrary lines or radically reorient First Amendment jurisprudence.

There is no way to definitively refute these arguments. Perhaps inclusion of algorithmbased decisions illuminates just how far Free Speech jurisprudence has gone off the rails (to use a technical term), such that we need to remake it. Or perhaps algorithm-based decisions are such unattractive candidates for First Amendment inclusion that we should draw a somewhat arbitrary line excluding them.

In my view, any line between algorithm-based and human-based decisions would be unjustifiably arbitrary, so a radical reorientation is the more attractive of the two options in this context. ${ }^{107}$

105 On the Turing test, see D. Dowe and G. Oppy, The Turing Test, Stanford Encyclopedia of Philosophy (January 26, 2011), http://plato.stanford.edu/entries/turing-test (noting that a machine passes the Turing test when a person is unable to detect that she is conversing with a machine instead of a fellow person). On the legal implications of machines capable of meeting the Turing standard, see generally J. Boyle, Brookings Inst., Endowed by Their Creator? The Future of Constitutional Personhood (2011), p. 6, www.brookings.edu/research/ endowed-by-their-creator-the-future-of-constitutional-personhood: "In the coming century, it is overwhelmingly likely that constitutional law will have to classify artificially created entities that have some but not all of the attributes we associate with human beings.”

106 Of course, this assumes we would regard such machines as materially different from humans in the first place. As James Boyle has noted, our grandchildren might view such machines as rightfully entitled to all the protections of personhood. See Boyle, ibid. But I leave that scenario for another day.

107 Commerce Clause jurisprudence provides a point of comparison. Even after United States v. Lopez, the Supreme Court's interpretation of Congress's interstate commerce power has been so expansive that almost every imaginable piece of federal legislation is authorized by the commerce power. See 514 US 549, 567 (1995) (refusing to hold that "the possession of a gun in a local school zone" reflects economic activity that rises to the level of interstate commerce and thus implicates the commerce power); see also United States v. Morrison, 529 US 598 (2000) (holding a federal statutory remedy for the victims of gender-motivated violence unconstitutional because it did not comport with the Commerce Clause). Cf. Gonzales v. Raich, 545 US 1 (2005) (upholding the constitutionality of the Federal Controlled Substances Act as applied to intrastate, non-commercial cultivation and possession of marijuana under the Commerce Clause). Some of those concerned about this development (notably Justice Thomas) have argued for a radical reorientation of the Court's jurisprudence. See Lopez, ibid., 
But that does not answer the question whether a major revamping of First Amendment jurisprudence is in fact desirable, and none of the arguments in this chapter squarely addresses that question. The analysis in this chapter does, however, highlight the stakes involved (because of the growing importance of algorithms in our lives), and in that way may provide a boost to arguments for a radical reorientation of the existing jurisprudence. That said, it would be a fairly small boost. Encompassing algorithm-based decisions within the ambit of the Free Speech Clause is a natural and modest step. The profusion of computer algorithms designed by humans to do the work other humans once did may alter our economy, ${ }^{108}$ but it does not significantly change the First Amendment analysis. So long as humans are making substantive editorial decisions, inserting computers into the process does not eliminate the communication via that editing. ${ }^{109}$ Arguments for a radical revamping should stand or fall on other grounds.

at 584 (Thomas J. concurring) (arguing that the Court "ought to temper [its] Commerce Clause jurisprudence"); Morrison, ibid., at 627 (Thomas J. concurring) (criticizing the Court's "view that the Commerce Clause has virtually no limits" and advocating for a shift to a "standard more consistent with the original understanding"). Others have argued for drawing ad hoc, and arguably arbitrary, lines to limit the expansion of that power. Both of these positions were articulated (minus any concession of possible arbitrariness) in arguments against the constitutionality of the Affordable Care Act. Some advocates argued for a radical revamping of Commerce Clause jurisprudence. See, e.g., Brief for Virginia Delegate Bob Marshall et al. as Amici Curiae in Support of Respondents at 11-14, Dep't of Health \& Human Servs. v. Florida, 567 US 519 (2012) (No. 11-398), 2012 WL 484059 (February 13, 2012) (arguing for a reconsideration of the Court's Commerce Clause cases, particularly Wickard v. Filburn, 317 US 111 (1942), and United States v. Darby, 312 US 100 (1941)). Many more pushed for a distinction between activity and inactivity. They often acknowledged that the distinction was ad hoc, and that they preferred a more fundamental rethinking of Commerce Clause jurisprudence. But they saw the actioninaction distinction as a tenable way of limiting Commerce Clause expansion without entailing a radical reorientation of the jurisprudence. See, e.g., R. E. Barnett, Commandeering the People: Why the Individual Health Insurance Mandate Is Unconstitutional (2010) 5 NY Univ. J. Law Liberty 581, 619 ("Of course, like the distinction between economic and noneconomic activity, the activity-inactivity distinction would not perfectly distinguish between incidental and remote exercises of implied powers. But, however imperfect, some such line must be drawn to preserve chapter I's scheme of limited and enumerated powers."). Whatever the merits of that argument in the Commerce Clause context, I think drawing a line between algorithm-based and human-based decisions for purposes of First Amendment coverage is so arbitrary as to be undesirable.

108 See, e.g., E. Brynjolfsson and A. McAfee, Race against the Machine: How the Digital Revolution Is Accelerating Innovation, Driving Productivity, and Irreversibly Transforming Employment and the Economy (Digital Frontier Press, 2011) (arguing that innovations in information technology will, inter alia, destroy many jobs); Andrew Yang's 2020 Presidential Campaign (same).

109 Or so our computer overlords would have us believe. See Jeopardy! (ABC television broadcast, February 15, 2011) (documenting the reaction of Ken Jennings, the most successful Jeopardy! player of all time, upon realizing that he was going to lose to an IBM computer named Watson). In his final answer, Jennings paraphrased the venerable Simpsons: "I for one welcome our new computer overlords" (ibid.). See also M. Maerz, Watson Wins “Jeopardy!” Finale; Ken Jennings Welcomes “Our New Computer Overlords,” Los Angeles Times (February 16, 2011), https://latimesblogs.latimes.com/showtracker/2011/oz/watson-jeopardy-finale-man-vs-machine-

showdown.html; Ratzule, Watson the New Computer Overlord, YouTube (February 16, 2011), www .youtube.com/watch?v=Skfw282flak (video of Jennings's answer and Watson's victory). 